\title{
The dynamics of homeownership among the 50+ in Europe
}

\author{
Viola Angelini • Agar Brugiavini • Guglielmo Weber
}

Received: 14 February 2012 / Accepted: 21 June 2013

(C) Springer-Verlag Berlin Heidelberg 2013

\begin{abstract}
We use life history data covering households in 13 European countries to analyse residential moves past the age of 50. We observe four types of moves: renting to owning, owning to renting, trading up or trading down for homeowners. We find that in the younger group (aged 50-64), trading up and purchase decisions prevail; in the older group (65+), trading down and selling are more common. Overall, moves are rare, particularly in countries characterised by high transaction costs. Most moves are driven by changes in household composition (divorce, widowhood, nest leaving by children), but economic factors play a role: low-income households who are house-rich and cash-poor are more likely to sell their home late in life.
\end{abstract}

Keywords Housing $\cdot$ Life cycle $\cdot$ Ageing $\cdot$ SHARELIFE

JEL Classifications D91 $\cdot$ E21 $\cdot$ J14

Responsible editor: Alessandro Cigno

V. Angelini

Department of Economics, Econometrics and Finance, University of Groningen, Nettelbosje 2, 9747AE Groningen, The Netherlands

\author{
A. Brugiavini \\ Department of Economics, Ca'Foscari University of Venice, \\ Cannaregio 873, 30121 Venice, Italy \\ G. Weber $(\bowtie)$ \\ Department of Economics and Management, University of Padua, \\ Via del Santo 33, 35123 Padova, Italy \\ e-mail: guglielmo.weber@unipd.it
}




\section{Introduction}

Housing is the most widely held asset for individual investors and, therefore, an important component of household wealth in many European countries. Over $70 \%$ of households aged 50 or over are homeowners, and this fraction is relatively stable at older ages. Understanding the reasons why individuals choose to own their home and fail to reduce housing equity by trading down or moving into rented accommodation in the last years of their life is an interesting research agenda for economists and social scientists in general and has important policy implications in ageing societies.

Compared to other forms of savings for old age, homeownership offers some advantages. Purchasing a home is similar to purchasing an annuity to insure housing consumption (by owning their home, consumers can insure against the risk of rent inflation; Sinai and Souleles 2005). Moreover, the home may be seen as a secure asset in case of need and perceived as a substitute for the purchase of long-term care insurance. It is also a family asset that may be transmitted to the next generation. These advantages are weighted against the drawbacks of overconsumption in old age (for those who are house-rich and cash-poor), low portfolio diversification (the price risk may be important if all assets are in the home) and illiquidity (drawing equity in case of need is not easy).

In order to preserve a good standard of living, elderly individuals should release home equity, by either taking up a mortgage, or by downsizing, or by selling and moving into rented accommodation. The life cycle model of saving under borrowing constraints predicts a hump-shaped homeownership age profile (Artle and Varaiya 1978). The ownership rate increases with age as people save and become homeowners and declines in old age as people draw on their housing equity. This is in sharp contrast with what we observe in the data, as stressed by Venti and Wise (2004) and more recently by Banks et al. (2012).

We know from the first two waves of the Survey of Health, Ageing and Retirement in Europe (SHARE) that large fractions of households report difficulties making ends meet. This is particularly true of renters, but is quite common among homeowners as well. In fact, Angelini et al. (2009) argue that the failure to use financial instruments that reduce home equity (like mortgages or reverse mortgages) late in life is partly responsible for financial hardship among elderly Europeans. The alternative way to reduce home equity, which involves trading down on the housing ladder, is reportedly rarely used, but evidence on this point is mostly anecdotal. Chiuri and Jappelli (2010) use repeated cross-sectional data on 15 countries of the Organisation for Economic Co-operation and Development (OECD) to show that few households cease to be homeowners late in life.

In this paper, we use life history data from the third wave of SHARE (known as SHARELIFE) to estimate age-tenure profiles and transition probabilities from owning to renting or to owning a smaller unit in old age. SHARELIFE is a unique data source that exploits recall information on respondents' life histories in a number of domains, including home moves, changes in demographics (marriage, divorce, birth of children and their nest leaving), changes in jobs and retirement, periods of unemployment, hunger, poor health and financial hardship, as well as living conditions at 
age 10. The recent volume edited by Börsch-Supan et al. (2011) gives a first partial account of the many domains covered by the survey.

Thanks to the richness of the data, we are able to address the issue of housing mobility over the life cycle, compare the homeownership age profiles of those currently 50 or more years old across countries and cohorts, and study what makes households more likely to move and change their housing tenure. Of particular interest is the question of whether and to what extent "house-rich, cash-poor" elderly households draw down housing wealth during retirement. We show in this paper how the downsizing decision is related not only to a number of shocks that affect individuals but also to the availability of mortgage instruments and an adequate level of income.

Our estimation strategy focuses on housing transitions in the second half of the life cycle. For this reason, we use the life history data to construct a panel, where each individual appears at all ages past the age of 50 up to the current age. For instance, we ask the following: What is the chance that 60-year-old individuals change their housing tenure choice within a year, as a function of time-invariant characteristics, initial conditions (as of age 60) and changes in relevant variables?

Housing choice transitions are characterised as follows: a first group of individuals has no change or moves from rent to rent; a second group moves from rent (age 60) to own (age 61); a third group changes from own (age 60) to rent (age 61); a fourth group trades down by selling and buying a cheaper home; and a fifth group instead trades up by selling and buying a more expensive home.

Conditioning variables are time-invariant characteristics (such as living conditions and school performance at age 10, that capture long-term access to resources), level variables (demographics, employment status, health, permanent income, stress, financial distress, all taken at age 60) and their changes between 60 and 61 (nest leaving by the children, bereavement, divorce, retirement, changes in stress, financial distress etc.).

In our analysis, we first document some patterns in the data concerning mobility and homeownership age profiles for three different cohorts (generations) in 13 European countries. We then investigate patterns of housing transitions by running a simple logit regression for renters, whose choice is whether to stay renters or become owners, and a multinomial logit for owners, who face a wider choice set, that includes trading up, down, moving into rented accommodation or staying in their present accommodation. This analysis highlights the need to explain why so few elderly homeowners release equity by trading down or moving into rented accommodation.

We therefore discuss results from a model that provides us with a richer framework of analysis to investigate the determinants of the choice of 65+ homeowners to sell and become renters, recently developed in important papers by Yang (2009) and Nakajima and Telyukova (2011). The former paper investigates the role of transaction costs in deterring sales among elderly homeowners. The latter paper stresses the role of housing wealth in explaining limited wealth decumulation past the retirement age in the USA. Our empirical analysis on European data not only brings out the importance of economic variables but also confirms the overarching role played by changes in health and demographics late in life. 
The paper is organised as follows: in Section 2, we present the data and provide some graphical evidence and descriptive statistics on number of moves by age and country and homeownership age profiles. In Section 3, we document the number of transactions over the life course and present estimation results of the transition probabilities past the age of 50 separately for current owners and current renters, by age band (50-64, 65 and over). This section highlights the need for a more thorough investigation on the probability of moving from homeownership to renting late in life that is carried out in Section 4. Section 5 concludes.

\section{Some facts on residential mobility and homeownership rates}

In this paper, we use data from the third wave of SHARE, which include information on the life histories of almost 30,000 respondents in 13 European countries, ranging from childhood major health events, to accommodation and parental background, to complete work, accommodation and health histories during adulthood.

These data provide information on individual respondents since they left their parental home. This implies that we have information on housing tenure choices made by respondents and their spouses over the course of their lives only when this was accompanied by a physical move to a different place of residence (or domicile). Changes in housing tenure that were not accompanied by a move are not recorded. Thus, we do not observe the purchase of the place of residence from the landlordprivate or public as it may be-or its inheritance on the one hand; home reversion contracts on the main residence (also known as the sale of the naked ownership) on the other.

We do know about moves that do not involve a change in housing tenure, for instance, those that involve the sale of the old home and purchase of a new one, and can even tell if such a move involved a positive or negative cash outlay, given that individuals report sale and purchase prices of the homes they owned.

What we can very well investigate with these data is individual housing mobility. A first indication of housing mobility is given by the total number of homes individuals ever had in their lifetime (so far). This information can be compared across countries.

Figure 1 shows that there are major differences across European countries: Northern Europeans report an average number of six to eight different main residences over their life course, whilst Southern and Eastern Europeans typically report less than four. Given that this includes the parental home, an average Greek, Polish or Czech apparently moved only once after the time of nest leaving.

If we are interested in what people do in relatively older ages, it makes sense to look at the number of main residences owned or rented after age 50. We know from previous studies that non-durable consumption peaks around that age (Attanasio et al. 1999), and household size also tends to decrease after that age (with important crosscountry differences). Figure 2 shows that, in most countries, a majority of individuals never change main residence after they reach the age of 50: only in Denmark, Sweden and The Netherlands the average number of main residences exceeds or comes close to the 1.5 mark. 


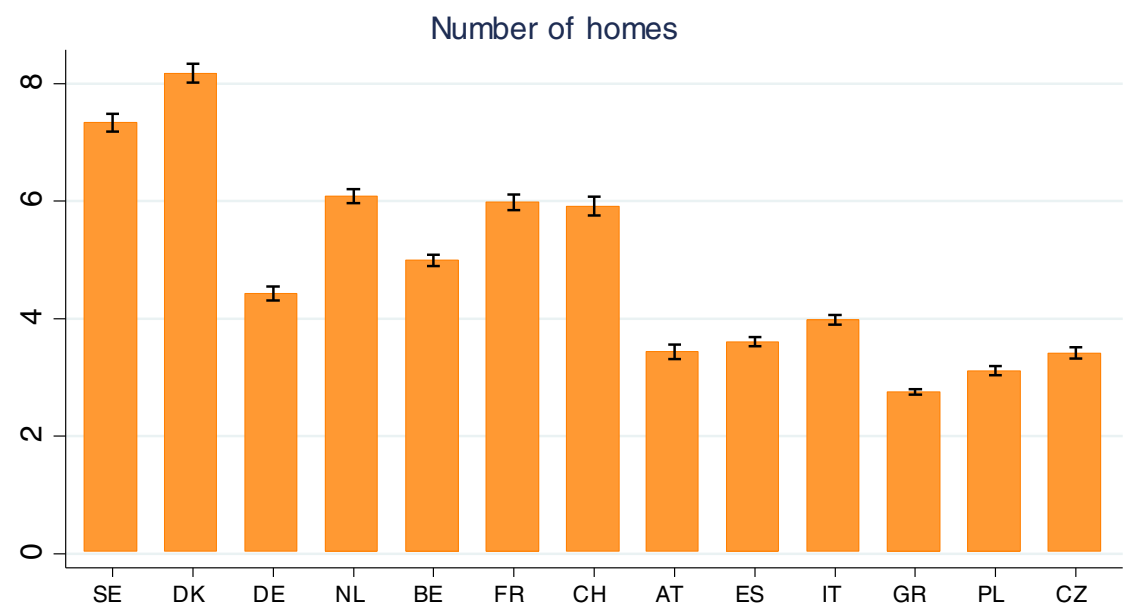

Fig. 1 Average numbers of main residences by country

Lower mobility in old age is in line with the predictions of the life cycle model with liquidity constraints and transaction costs, as stressed by Yang (2009). Indeed, Yang reports on the proportions of households who, according to the US CPS, moved over 5-year age brackets. For instance, $24 \%$ of households (whose head was) aged 55 in 2005 had moved over the previous 5-year period (that is, over the 50-54 age bracket), and $22 \%$ of the 60 years old had done likewise; this proportion falls to $18 \%$ for the 65 years old down to $17 \%$ for the 70 years old, $15 \%$ for the 75 years old and slightly up to $16 \%$ for the 80 years old (75-79 age bracket). In our data, we can compute similar statistics at the individual level, using information on the

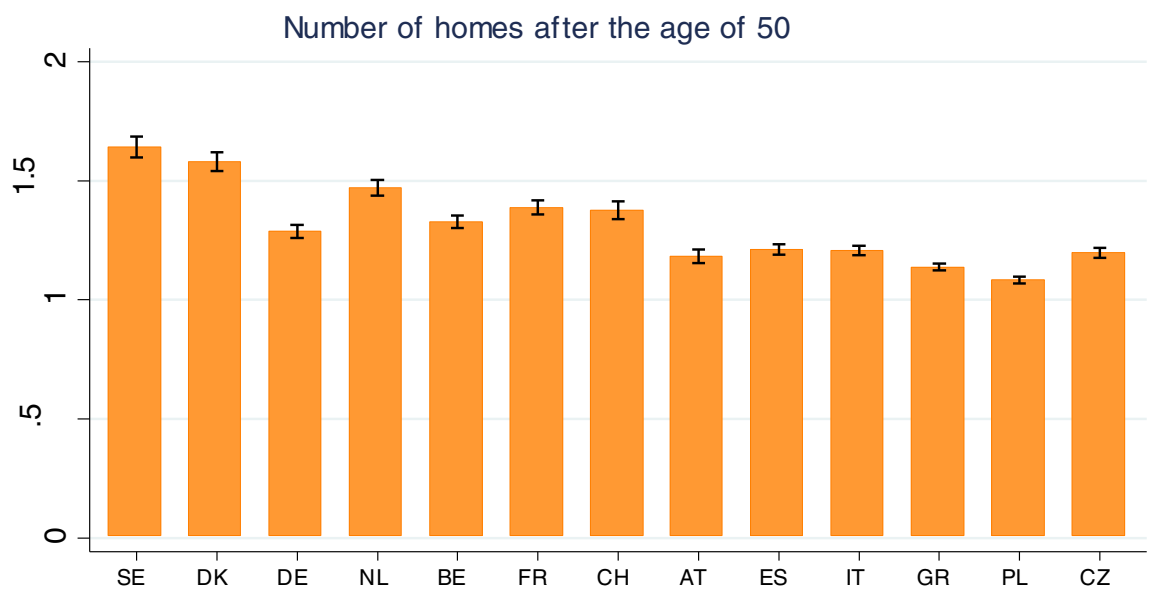

Fig. 2 Average numbers of main residences by country past the age of 50 
age at which respondents moved in the past. Thus, our transitions refer to different periods of time (an 80-year-old in 2009 was 50-54 back in 1979-1984, a 60-yearold in 1999-2004) and to a different sampling unit (the individual rather than the household), but are nonetheless interesting to compare. We find that in the European countries we consider transitions also fall with age, but from much lower levels: from $7.13 \%$ (at ages 50-54) down to $4.66 \%$ (at ages 75-79). The proportion of transitions in the oldest age group (that Yang does not consider) is higher (9.36\%), but this is based on a relatively small sample and more importantly includes moves to nursing homes (mostly in Northern Europe) or to children's homes (mostly in Southern Europe) that are largely driven by loss of spouse and adverse health shocks.

The fall in mobility with age (up to age 79) is a common feature in all countries that we consider. In Sweden, we observe the largest proportion of transitions ( $11.90 \%$ for the $50-54$ age group, $9.21 \%$ for the $75-79$ age group), but the age pattern is much less pronounced compared to that of France (from 8.37 to $1.19 \%$ ), The Netherlands (from 8.33 to $4.71 \%$ ), Germany (from 4.39 to $0.34 \%$ ) or Italy (from 4.42 to $0.20 \%)$. Very low transition rates at all ages are observed in Greece $(0.92 \%$ at most), Poland and the Czech Republic (always lower than $2.5 \%$ ).

An issue we can investigate using our data is the prevalence of homeownership across countries - in fact, we are able to plot age profiles for at least three cohorts of individuals, something that cannot be done using cross section or even short panel data, as stressed by Angelini et al. (2011).

Figure 3 presents homeownership age profiles for three different generations (or year-of-birth cohorts). Cohort 1 consists of individuals born before 1935; cohort 2, of individuals born between 1935 and 1944; and cohort 3, of individuals born between 1945 and up to 1954. An individual is defined as a homeowner if he or she owned at least part of the main residence at the time of his or her latest move (as explained above, changes in ownership that do not involve a move are not recorded in the data).

The age profiles look quite similar nearly everywhere: an increase in homeownership up to age 50-59, then a levelling up and a small moving out of ownership in old age, after 70 in Denmark, Sweden and The Netherlands, and rather after age 80 in the other countries (except Poland and Greece where no moving out of homeownership is apparent).

The figure shows marked cohort effects in some, but not all, countries: The Netherlands, Sweden, France and the Czech Republic display three distinct lines, at least until relatively late ages. In other countries (France, Spain and Switzerland), there is a marked difference between the oldest cohort and the other two.

A point worth making is that these plots refer to individual ownership: a wife who lives with her husband will be considered a homeowner only if she owns at least part of their home. Some of the cohort (and even age) effects could thus be due to different laws/customs involving joint or separate ownership of a couple's main residence, and may also be affected by bereavement (a woman may become homeowner when her husband dies). As a way to check for the importance of this issue, we plotted homeownership age profiles by gender (not reported but available from the authors upon request). For most countries, the plots are very close to those reported in Fig. 3. In four countries, instead, we detect some differences. For these countries, we display gender-specific age profiles in Fig. 4. 


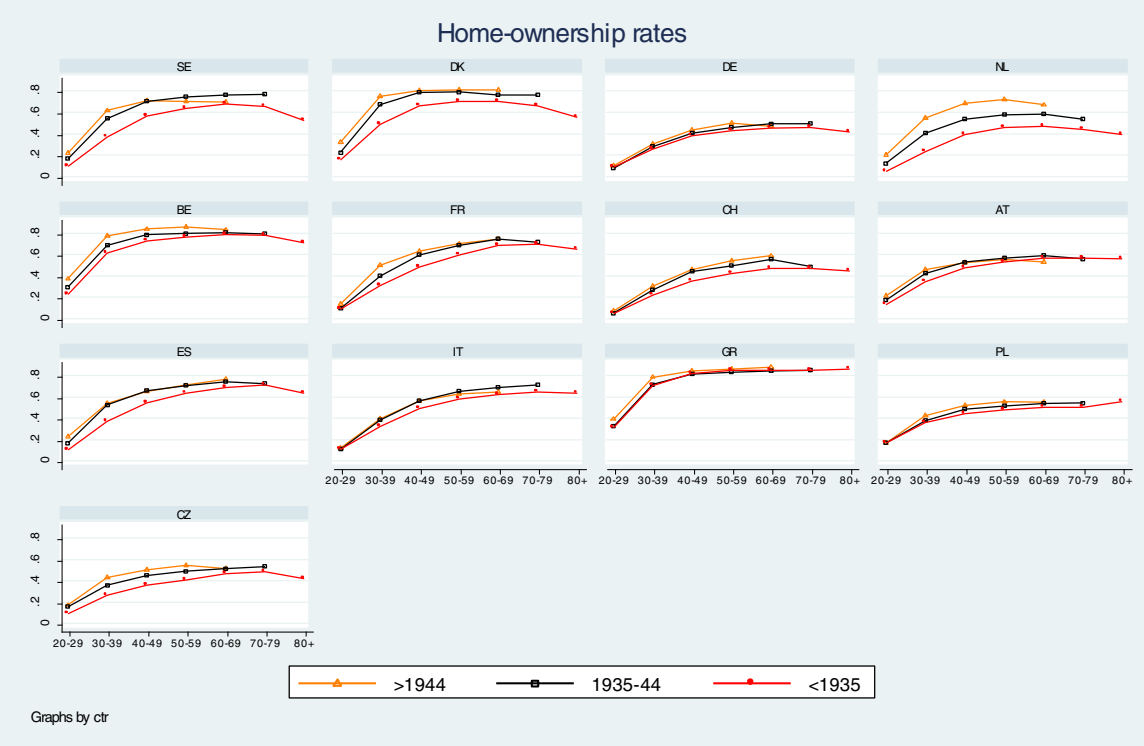

Fig. 3 Homeownership age profiles by country and cohort

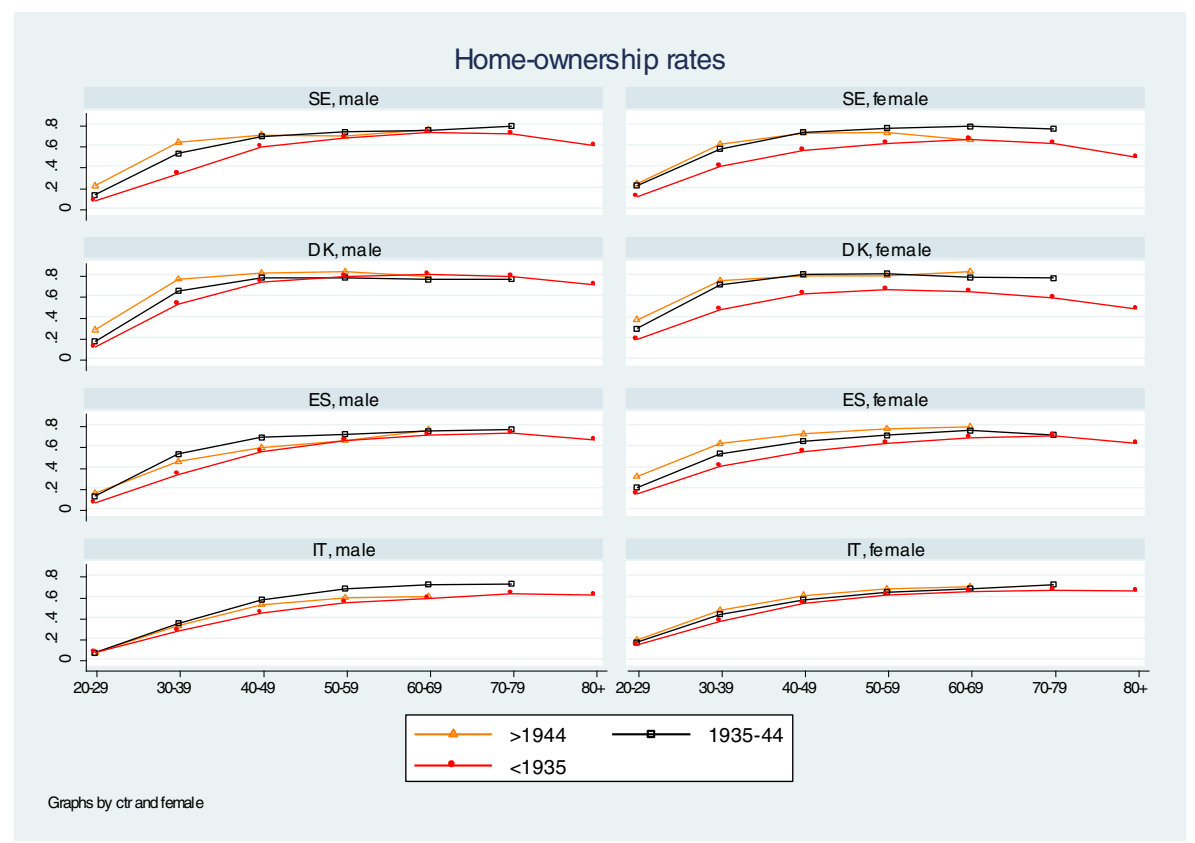

Fig. 4 Homeownership age profiles by sex, country and cohort 
We see that the countries where gender differences are noticeable are Sweden, Denmark, Spain and Italy. Cohort effects are much stronger for women in the first three countries and for men in Italy. Only in Denmark (and to some extent Sweden) the negative cohort effect for the oldest cohort of women persists to the end of the age range. In Spain, there is convergence of the three lines around age 60, whilst the negative cohort effect for the oldest cohort of Italian men persists until late ages.

Because of the evidence shown above, we check in our empirical analysis if estimation results are the same for men and women (they normally are).

\section{Housing transitions and transition probabilities}

One of the interesting issues we intend to investigate is what makes people more likely to move, particularly if this move involves a change in housing tenure or a change in the financial resources available to an individual (trading down or trading up). The best way to address this question is to create a panel out of the life history data in which each individual contributes as many observations as there are years of age.

The type of question the data so arranged can help addressing is the following: what is the chance that a 60-year-old (say) changes its housing tenure choice within a year, as a function of both initial conditions (as of age 60) and of changes in relevant variables?

We can define our dependent variable $\Delta y$ that denotes changes in housing choice as follows: it takes a value 0 if there is no change or there is a move from rent to rent over the period; value 1 if there is a change from rent (age 60) to own (age 61); value 2 if there is a change from own (age 60) to rent (age 61); value 3 if own-own down; and value 4 if own-own up. Note that there is no natural ordering of these transitions, so the values we attach to $\Delta y$ are entirely arbitrary.

Conditioning variables are level variables prior to the period (demographics, health, financial hardship at age 59) and their changes between 59 and 60 (nest leaving, bereavement, divorce, retirement, better or worse health, start or end of financial hardship). Also, we consider early life condition indicators, which proxy for access to lifetime resources, and a set of country, age and time dummies.

In practice, for computational convenience and given the low incidence of transitions over single years of age, we take larger age brackets: 50-54, 55-59, 60-64, $65-69,70-74,75-79,80$ and over. If more than a change occurs between ages 55 and 60, we ignore it and focus on the change between ages 55 and 60. Initial conditions are computed at 55, changes between 55 and 59 for those who do not change in between, between 55 and " $a-1$ " if a change occurs at age " $a$ ".

In Table 1, we report the actual number of transitions that we record for each age bracket. For instance, we find that only $5.15 \%$ individuals experienced a residential move between ages 50 and 54. The fraction of movers steadily declines with age (to $3.1 \%$ immediately past the retirement age, to $2.4 \%$ in the late $70 \mathrm{~s}$ ), as discussed in the previous section (but at lower rates, because rent-to-rent moves are not counted here). Overall, for most individuals, we see no change within any age bracket. This is in line with the relatively low housing mobility among the 50+ as observed in Fig. 2. 
Table 1 Housing transitions by age bracket

\begin{tabular}{llcllrr}
\hline \multirow{2}{*}{ Age bracket } & \multicolumn{2}{l}{ Housing transitions } & & & \\
\cline { 2 - 6 } & No change & Rent-own & Own-rent & Own down & Own up & Total \\
\hline $50-54$ & 21,925 & 575 & 201 & 216 & 212 & 23,129 \\
$55-59$ & 19,763 & 434 & 132 & 204 & 155 & 20,688 \\
$60-64$ & 15,805 & 302 & 118 & 160 & 104 & 16,489 \\
$65-69$ & 11,745 & 158 & 110 & 93 & 58 & 12,164 \\
$70-74$ & 8,188 & 45 & 106 & 56 & 27 & 8,422 \\
$75-79$ & 5,073 & 27 & 80 & 37 & 13 & 5,230 \\
$80+$ & 2,548 & 6 & 113 & 18 & 8 & 2,693 \\
Total & 85,140 & 1,547 & 860 & 784 & 577 & 88,815 \\
\hline
\end{tabular}

However, we do observe a number of transitions, particularly in some countries, and these are the subject of our empirical investigation.

First of all, we see many transitions from rent to own prior to age 65-we stress that "rent" includes here any type of accommodation that is not at least partly owned by the respondent. These transitions are most frequent in France, Switzerland, Spain, Italy and Sweden. Some could be due to inheritance because of death of one's parents-however, in the age brackets 50-64 inheritance accounts for $11 \%$ of all moves from renting to owning. This type of transitions becomes less frequent past the age of 65 .

The opposite transition, from owning to renting, is also relatively common-and becomes the most common at ages over 65 . This type of transition can be considered a form of downsizing or trading down, at least in wealth terms. ${ }^{1}$

The cut-off of 65 years of age roughly corresponds to retirement age in most European countries and marks a natural watershed in asset accumulation decisions. Table 1 also suggests that individuals younger than 65 are more likely to be trading up in the housing market, whilst individuals past age 65 are instead more likely to be trading down in the housing market.

For these reasons, in the sequel, we report descriptive statistics and (later) parameter estimates of transition equations by broader age groups: all observations on individuals aged less than 65 on the one hand, 65 or over on the other hand.

In Table 2, we report descriptive statistics for the variables used in our estimation. We can distinguish three groups of explanatory variables:

1. a first group of variables captures demographic characteristics (female, married, number of children and number of children living at home) and events (widowhood, divorce and nest leaving in the 5 years under consideration) which typically affect housing decisions,

\footnotetext{
${ }^{1}$ For instance, Attanasio et al. (2011) leave the housing tenure choice past the age of 60 unexplained, for lack of a plausible economic rationale of the widespread homeownership in old age.
} 
Table 2 Descriptive statistics by age group

\begin{tabular}{|c|c|c|c|c|}
\hline & \multicolumn{2}{|c|}{ Younger than 65} & \multicolumn{2}{|c|}{ Older than 65} \\
\hline & Mean & St. dev. & Mean & St. dev. \\
\hline Homeowner & 0.670 & 0.470 & 0.658 & 0.474 \\
\hline No change & 0.955 & 0.207 & 0.968 & 0.176 \\
\hline Female & 0.540 & 0.498 & 0.546 & 0.498 \\
\hline Childless & 0.091 & 0.288 & 0.101 & 0.302 \\
\hline Number of children ever & 2.212 & 1.355 & 2.302 & 1.510 \\
\hline Married & 0.888 & 0.316 & 0.747 & 0.435 \\
\hline Widowhood & 0.020 & 0.140 & 0.049 & 0.216 \\
\hline Divorce & 0.009 & 0.096 & 0.002 & 0.049 \\
\hline No. children at home start year & 1.066 & 1.221 & 0.409 & 0.901 \\
\hline Nest leaving of children & 0.257 & 0.437 & 0.058 & 0.233 \\
\hline Age at nest leaving & 23.279 & 6.368 & 24.171 & 7.087 \\
\hline Poor health & 0.119 & 0.323 & 0.186 & 0.389 \\
\hline Worse health & 0.085 & 0.279 & 0.046 & 0.209 \\
\hline Better health & 0.073 & 0.259 & 0.089 & 0.285 \\
\hline Hardship & 0.068 & 0.251 & 0.049 & 0.216 \\
\hline Start of hardship & 0.013 & 0.115 & 0.005 & 0.068 \\
\hline End of hardship & 0.015 & 0.122 & 0.005 & 0.070 \\
\hline \multicolumn{5}{|l|}{ Early life conditions } \\
\hline Many books & 0.294 & 0.456 & 0.225 & 0.418 \\
\hline Overcrowding & 0.298 & 0.457 & 0.338 & 0.473 \\
\hline Good at mathematics & 0.328 & 0.470 & 0.314 & 0.464 \\
\hline Good at verbal & 0.336 & 0.472 & 0.324 & 0.468 \\
\hline
\end{tabular}

2. a second group measures general conditions (poor health, financial hardship) and their changes (better health, worse health, start of financial hardship, end of financial hardship) before the time when the housing change takes place, and

3. a third group of variables (many books, overcrowding, good at math, good at literature) represents "early life conditions", as measured at the age of 10.

Finally, the variable "age at nest leaving" indicates the point over the life cycle when respondents left the parental home (for those who ever did, a small fraction never did), as this may capture their taste for mobility.

Table 2 shows that two thirds of the individuals are homeowners, and the proportions are quite similar across the two age bands. For most individuals, no transition occurs over each of the 5-year period, but inaction is slightly more common among the 65+. The proportion of females is almost identical (around 54-55\%), and the number of children respondents ever had is slightly larger for the $65+$, but not by a wide margin (2.3 instead of 2.2). Marriage is much more common among the younger 
group - many more are single past the age of 65 because they lost their spouse sometime in the past. The proportion of individuals who recently (past 5 years) lost their spouse ("widowhood") is $2.1 \%$ in the younger group and $5 \%$ in the older one. A recent divorce is instead quite rare (less than $1 \%$ ), particularly for the 65+. Important differences emerge when we look at the number of children living with the respondents - 1.066 for the younger group, 0.409 for the older one-and who left the parental home over the 5 years $(0.257$ versus 0.058$)$. Poor health (self-reported) is much more common among the $65+$, but health seems to improve more/worsen less for the $65+$ than for the younger age group. Financial hardship affects roughly 5-6\% of the sample and is more common among the younger, and changes in financial hardship are mostly concentrated among the younger age group. Finally, early life conditions were better for the younger group, whilst relative school performance at age 10 in mathematics and literature is quite stable.

In Tables 3, 4 and 5, we report parameter estimates and standard errors of a simple model that explains transition probabilities. This model should be seen as a way to describe the data and highlight correlations that deserve further investigationsomething that is done in the next section.

Table 3 presents estimates of a multinomial logit where the categories are "own to rent" (column 1), "own down", i.e. downsize (column 2), and "own up" (column 3); the reference group are individuals who report no change and remain owners of the same home. These estimates are carried out on the sample of individuals aged 50-64.

The results show that the demographic events are very important for changes in housing arrangements in the younger age group; particularly, the events "widowhood" and "divorce" make it more likely to move into rented accommodation or to trade down (or even to trade up), whilst being married decreases the probability of selling and becoming renters. Childless individuals are less likely to go into rented accommodation, for reasons that will become clear in the next section. Nest leaving by children increases the probability to remain in the initially owned home, presumably because for the younger age group nest leaving (of one child) does not necessarily mean that all children have left. The respondent's age of leaving the parental home has little effect (it decreases all transition probabilities, but the coefficient is significant only in the last column at the $10 \%$ level).

Poor health makes a move more likely, perhaps because individuals need to find a home more suitable to their health condition. However, if health deteriorates, then moving becomes less likely because individuals might not be in the condition to undertake housing changes when ill. A health improvement has an even stronger, negative effect on all transition probabilities except the last one (trading up). The "early life conditions" do not seem to play a major role in this specification.

In Table 4, we present the same specification for the older age group. The "married" dummy has a significant negative sign for the own-to-rent category and widowhood is also very significant (with a positive sign). Divorce, which is quite rare in this age group, is highly significant, making it more likely to trade down or move into rented accommodation and less likely to trade up. By and large, the demographic variables detecting relevant demographic events are much less important for the older age group. Poor health makes it more likely to move in the older group, possibly to a nursing home (which is part of the "rented" accommodation category), but 
Table 3 Estimates of multinomial logit for homeowners aged less than 65

\begin{tabular}{|c|c|c|c|}
\hline Variables & $\begin{array}{l}1 \\
\text { Own-rent }\end{array}$ & $\begin{array}{l}2 \\
\text { Own down }\end{array}$ & $\begin{array}{l}3 \\
\text { Own up }\end{array}$ \\
\hline Female & $\begin{array}{c}0.178 \\
(0.119)\end{array}$ & $\begin{array}{r}-0.0316 \\
(0.100)\end{array}$ & $\begin{array}{c}-0.307 * * * \\
(0.107)\end{array}$ \\
\hline Childless & $\begin{array}{r}-0.480 * \\
(0.266)\end{array}$ & $\begin{array}{r}-0.0450 \\
(0.248)\end{array}$ & $\begin{array}{c}0.0883 \\
(0.222)\end{array}$ \\
\hline Number of children & $\begin{array}{c}0.0220 \\
(0.0609)\end{array}$ & $\begin{array}{l}0.200 * * * \\
(0.0534)\end{array}$ & $\begin{array}{r}-0.0761 \\
(0.0633)\end{array}$ \\
\hline Married & $\begin{array}{c}-0.822 * * * \\
(0.179)\end{array}$ & $\begin{array}{r}-0.0807 \\
(0.188)\end{array}$ & $\begin{array}{c}0.176 \\
(0.202)\end{array}$ \\
\hline Widowhood & $\begin{array}{l}1.217 * * * \\
(0.260)\end{array}$ & $\begin{array}{l}0.805^{* * *} \\
(0.267)\end{array}$ & $\begin{array}{r}-0.658 \\
(0.583)\end{array}$ \\
\hline Divorce & $\begin{array}{l}3.548 * * * \\
(0.182)\end{array}$ & $\begin{array}{l}1.498 * * * \\
(0.284)\end{array}$ & $\begin{array}{l}0.920 * * \\
(0.396)\end{array}$ \\
\hline No. children in starting year & $\begin{array}{c}0.0596 \\
(0.0686)\end{array}$ & $\begin{array}{c}-0.0421 \\
(0.0618)\end{array}$ & $\begin{array}{c}0.0269 \\
(0.0654)\end{array}$ \\
\hline Nest leaving of children & $\begin{array}{c}-0.963 * * * \\
(0.162)\end{array}$ & $\begin{array}{c}-0.803 * * * \\
(0.146)\end{array}$ & $\begin{array}{c}-0.993 * * * \\
(0.164)\end{array}$ \\
\hline Age at nest leaving & $\begin{array}{r}-0.00349 \\
(0.0127)\end{array}$ & $\begin{array}{r}-0.0152 \\
(0.0127)\end{array}$ & $\begin{array}{r}-0.0213^{*} \\
(0.0125)\end{array}$ \\
\hline Poor health & $\begin{array}{l}1.062^{* * * *} \\
(0.189)\end{array}$ & $\begin{array}{l}1.213 * * * \\
(0.153)\end{array}$ & $\begin{array}{l}0.818 * * * \\
(0.193)\end{array}$ \\
\hline Worse health & $\begin{array}{c}-1.817 * * * \\
(0.389)\end{array}$ & $\begin{array}{c}-1.948 * * * \\
(0.383)\end{array}$ & $\begin{array}{c}-2.129 * * * \\
(0.455)\end{array}$ \\
\hline Better health & $\begin{array}{c}-3.475^{* * *} \\
(0.622)\end{array}$ & $\begin{array}{c}-2.564 * * * \\
(0.353)\end{array}$ & $\begin{array}{c}-1.917^{* * *} \\
(0.371)\end{array}$ \\
\hline Hardship & $\begin{array}{l}0.568 * * \\
(0.269)\end{array}$ & $\begin{array}{l}0.649 * * * \\
(0.250)\end{array}$ & $\begin{array}{r}-0.175 \\
(0.338)\end{array}$ \\
\hline Hardship start & $\begin{array}{c}0.322 \\
(0.456)\end{array}$ & $\begin{array}{r}-0.616 \\
(0.743)\end{array}$ & $\begin{array}{c}-15.78 * * * \\
(0.133)\end{array}$ \\
\hline Hardship end & $\begin{array}{r}-0.624 \\
(0.544)\end{array}$ & $\begin{array}{c}-1.414^{* *} \\
(0.632)\end{array}$ & $\begin{array}{r}-1.390 \\
(1.055)\end{array}$ \\
\hline Many books & $\begin{array}{c}0.0948 \\
(0.123)\end{array}$ & $\begin{array}{l}0.310^{* * *} \\
(0.106)\end{array}$ & $\begin{array}{c}0.0817 \\
(0.115)\end{array}$ \\
\hline Overcrowd & $\begin{array}{l}0.299 * * \\
(0.140)\end{array}$ & $\begin{array}{l}0.00161 \\
(0.141)\end{array}$ & $\begin{array}{c}0.0676 \\
(0.144)\end{array}$ \\
\hline Good mathematics & $\begin{array}{c}0.0940 \\
(0.125)\end{array}$ & $\begin{array}{c}0.0976 \\
(0.109)\end{array}$ & $\begin{array}{c}0.103 \\
(0.121)\end{array}$ \\
\hline Good verbal & $\begin{array}{c}0.0125 \\
(0.124)\end{array}$ & $\begin{array}{c}0.0627 \\
(0.108)\end{array}$ & $\begin{array}{c}0.134 \\
(0.123)\end{array}$ \\
\hline
\end{tabular}


Table 3 (continued)

\begin{tabular}{llcc}
\hline Variables & 1 & 2 & 3 \\
& Own-rent & Own down & Own up \\
\hline Constant & $-2.749^{* * *}$ & $-3.140^{* * *}$ & $-2.545^{* * *}$ \\
Observations & $(0.462)$ & $(0.455)$ & $(0.441)$ \\
\hline
\end{tabular}

All specifications include a full set of country, age bracket and decade dummies. Reference group: no change. Robust standard errors in parentheses

$* p<0.1 ; * * p<0.05 ; * * * p<0.01$

a health improvement strongly reduces all transition probabilities. Hardship episodes are quite rare, but have important effects. Most early life condition indicators do not seem to be important determinants of moves at older ages, but our estimates suggest that having many books at the age of 10 reduces the probability of moving into rented accommodation.

Table 5 presents estimates based on a logit regression for the transition "rent to own" for individuals who are initially renting. Column 1 is for observations of individuals younger than 65, and column 2, for observations older than 65 .

Demographic events such as divorce increase the probability of moving from "rent" to "own" for the younger group; being married also increases this probability, whilst "nest leaving" has the opposite effect (it increases the probability of remaining in rented accommodation). Those who are still in the parental home are much less likely to buy, but for all the others, the age when they left the parental nest has no effect. Once again, "poor health" has a positive effect on the probability of a move, but health changes have a strong negative effect, whilst some of the early conditions seem to have a positive effect, suggesting that individuals who enjoyed better conditions early in life are more likely to become owners before age 65 . We cannot control for loss of parents in the regression, but we know that only $11 \%$ of moves from renting to owning in the younger age group are related to receiving the home as a gift or bequest.

The move from renting to owning among the $65+$ is quite rare, and very hard to predict. The only significant variables are the gender of the respondent (females are less likely to purchase), health improvement or deterioration and verbal abilities at age 10 .

In the specification, we do not include economic variables, except the experience of a hardship period. Unfortunately, we do not observe income or wealth over the life cycle, nor do we have information on mortgage availability or transaction costs over the long time period covered by our recall data. In the next section, we shall investigate the role of income and (housing) wealth for one particular group (retired homeowners) for which we can compute individual-level estimates of these variables. In this section, all we can do is to relate the estimated country effects to macro-level economic variables for which we have an estimate at a point in time. 
Table 4 Estimates of multinomial logit for homeowners aged 65 and over

\begin{tabular}{|c|c|c|c|}
\hline Variables & $\begin{array}{l}1 \\
\text { Own-rent }\end{array}$ & $\begin{array}{l}2 \\
\text { Own down }\end{array}$ & $\begin{array}{l}3 \\
\text { Own up }\end{array}$ \\
\hline Female & $\begin{array}{c}0.0966 \\
(0.127)\end{array}$ & $\begin{array}{c}-0.0314 \\
(0.155)\end{array}$ & $\begin{array}{r}-0.144 \\
(0.224)\end{array}$ \\
\hline Childless & $\begin{array}{c}-0.631 * * \\
(0.265)\end{array}$ & $\begin{array}{r}-0.0825 \\
(0.369)\end{array}$ & $\begin{array}{c}0.476 \\
(0.392)\end{array}$ \\
\hline Number of children & $\begin{array}{c}-0.114 * \\
(0.0611)\end{array}$ & $\begin{array}{c}0.112 \\
(0.0774)\end{array}$ & $\begin{array}{r}-0.128 \\
(0.101)\end{array}$ \\
\hline Married & $\begin{array}{c}-0.788^{* * *} \\
(0.138)\end{array}$ & $\begin{array}{r}-0.0941 \\
(0.210)\end{array}$ & $\begin{array}{c}0.438 \\
(0.339)\end{array}$ \\
\hline Widowhood & $\begin{array}{l}1.159 * * * \\
(0.195)\end{array}$ & $\begin{array}{c}0.322 \\
(0.339)\end{array}$ & $\begin{array}{r}-0.106 \\
(0.526)\end{array}$ \\
\hline Divorce & $\begin{array}{l}3.546^{* * *} \\
(0.452)\end{array}$ & $\begin{array}{l}2.248 * * * \\
(0.765)\end{array}$ & $\begin{array}{c}-31.75 * * * \\
(0.362)\end{array}$ \\
\hline No. children in starting year & $\begin{array}{l}0.262 * * * \\
(0.0844)\end{array}$ & $\begin{array}{r}-0.0503 \\
(0.142)\end{array}$ & $\begin{array}{l}0.241 * * \\
(0.107)\end{array}$ \\
\hline Nest leaving of children & $\begin{array}{c}-0.372 \\
(0.371)\end{array}$ & $\begin{array}{r}-0.814 \\
(0.751)\end{array}$ & $\begin{array}{r}-1.047 \\
(0.739)\end{array}$ \\
\hline Age at nest leaving & $\begin{array}{c}-0.0222 * \\
(0.0120)\end{array}$ & $\begin{array}{r}-0.0303 * \\
(0.0183)\end{array}$ & $\begin{array}{r}-0.00977 \\
(0.0168)\end{array}$ \\
\hline Poor health & $\begin{array}{l}0.961 * * * \\
(0.174)\end{array}$ & $\begin{array}{l}0.993 * * * \\
(0.235)\end{array}$ & $\begin{array}{c}0.479 \\
(0.340)\end{array}$ \\
\hline Worse health & $\begin{array}{r}-0.307 \\
(0.352)\end{array}$ & $\begin{array}{c}-16.65^{* * *} \\
(0.143)\end{array}$ & $\begin{array}{r}-1.418 \\
(1.014)\end{array}$ \\
\hline Better health & $\begin{array}{c}-3.027 * * * \\
(0.613)\end{array}$ & $\begin{array}{c}-2.143^{* * *} \\
(0.567)\end{array}$ & $\begin{array}{c}-1.822 * * \\
(0.805)\end{array}$ \\
\hline Hardship & $\begin{array}{r}-0.329 \\
(0.413)\end{array}$ & $\begin{array}{r}-0.737 \\
(1.028)\end{array}$ & $\begin{array}{l}0.00173 \\
(0.692)\end{array}$ \\
\hline Hardship start & $\begin{array}{c}0.893 \\
(0.717)\end{array}$ & $\begin{array}{c}-16.56^{* * * *} \\
(0.431)\end{array}$ & $\begin{array}{c}-16.59 * * * \\
(0.286)\end{array}$ \\
\hline Hardship end & $\begin{array}{c}-16.32 * * * \\
(0.468)\end{array}$ & $\begin{array}{c}-15.56^{* * * *} \\
(1.041)\end{array}$ & $\begin{array}{c}-16.98 * * * \\
(0.721)\end{array}$ \\
\hline Many books & $\begin{array}{c}-0.385^{* * *} \\
(0.140)\end{array}$ & $\begin{array}{r}-0.0291 \\
(0.166)\end{array}$ & $\begin{array}{c}0.208 \\
(0.233)\end{array}$ \\
\hline Overcrowd & $\begin{array}{c}0.0561 \\
(0.141)\end{array}$ & $\begin{array}{c}0.0666 \\
(0.188)\end{array}$ & $\begin{array}{r}-0.0249 \\
(0.279)\end{array}$ \\
\hline Good mathematics & $\begin{array}{r}-0.155 \\
(0.136)\end{array}$ & $\begin{array}{c}0.0382 \\
(0.169)\end{array}$ & $\begin{array}{r}-0.139 \\
(0.239)\end{array}$ \\
\hline Good verbal & $\begin{array}{r}-0.172 \\
(0.136)\end{array}$ & $\begin{array}{c}0.146 \\
(0.175)\end{array}$ & $\begin{array}{c}0.297 \\
(0.222)\end{array}$ \\
\hline
\end{tabular}


Table 4 (continued)

\begin{tabular}{lllc}
\hline Variables & 1 & 2 & 3 \\
& Own-rent & Own down & Own up \\
\hline Constant & $-0.722^{*}$ & $-2.811 * * *$ & $-4.385^{* * * *}$ \\
& $(0.389)$ & $(0.642)$ & $(0.768)$ \\
Observations & 16,615 & & \\
\hline
\end{tabular}

All specifications include a full set of country, age bracket and decade dummies. Reference group: no change. Robust standard errors in parentheses

$* p<0.1 ; * * p<0.05 ; * * * p<0.01$

In particular, we can use data on the maximum loan-to-value ratio prevailing in each country in the early 1990s (when most transitions took place) and see how this correlates with the purchase probability for renters. Figure 5 shows that there is a positive correlation for those aged 50-64: in countries with more liberal access to credit (higher loan-to-value ratio), the odds ratio of becoming a homeowner was higher. For the other transition probabilities we estimated, and for the older age bracket, the effect of the loan-to-value ratio is less strong.

\section{Why elderly Europeans do not draw down home equity}

We saw in Section 2 that there is some downsizing past the age of 65, but that this is relatively rare. Table 1 reveals that there are 300 transitions from homeownership to rented accommodation and 172 moves from a more expensive to a less expensive home. Given that we observe a total of 28,509 potential transitions (most of which is characterised by no change), the incidence of downsizing is a mere $1.65 \%$ over each 5-year period. Estimation results in Table 4 suggest that poor health and the loss of a spouse make people more likely to move from owning to renting, whilst being married and having many books as a child make people less likely to take this option.

If we want to understand why so few downsize, and in response to what changes people choose to downsize, we need a formal theoretical model. Most of the literature on demand for housing simply assumes the presence of a bequest motive to explain why the elderly do not downsize, but this is far from convincing, given that liquid wealth can as easily be bequeathed. ${ }^{2}$

In an important paper, Nakajima and Telyukova (2011) have addressed the issue of home equity release late in life in a full-blown life cycle model under uncertainty that specifically addresses the issue of the contribution of housing wealth to the observed

\footnotetext{
${ }^{2}$ Unfortunately, we do not know the number of rooms of each accommodation, only of the current one; so, we cannot say whether financial downsizing is accompanied by a reduction in living space. Also, we do not observe spending on housing maintenance and repairs; given that the elderly often draw down their housing equity by cutting on maintenance, we fail to capture this type of housing wealth decumulation in old age.
} 
Table 5 Estimates of logit for renters (by age group)

\begin{tabular}{|c|c|c|}
\hline Variables & $\begin{array}{l}1 \\
\text { Rent-own } \\
\text { (under 65) }\end{array}$ & $\begin{array}{l}2 \\
\text { Rent-own } \\
\text { (over 65) }\end{array}$ \\
\hline Female & $\begin{array}{c}-0.149 * * \\
(0.0671)\end{array}$ & $\begin{array}{c}-0.529 * * * \\
(0.161)\end{array}$ \\
\hline Childless & $\begin{array}{c}-0.257 * * \\
(0.124)\end{array}$ & $\begin{array}{r}-0.233 \\
(0.279)\end{array}$ \\
\hline Number of children & $\begin{array}{r}-0.0250 \\
(0.0354)\end{array}$ & $\begin{array}{c}0.0203 \\
(0.0705)\end{array}$ \\
\hline Married & $\begin{array}{l}0.350 * * * \\
(0.105)\end{array}$ & $\begin{array}{c}0.280 \\
(0.205)\end{array}$ \\
\hline Widowhood & $\begin{array}{c}0.378 * \\
(0.197)\end{array}$ & $\begin{array}{c}0.352 \\
(0.325)\end{array}$ \\
\hline Divorce & $\begin{array}{l}0.972 * * * \\
(0.227)\end{array}$ & $\begin{array}{c}0.501 \\
(0.740)\end{array}$ \\
\hline No. children in starting year & $\begin{array}{c}0.0101 \\
(0.0393)\end{array}$ & $\begin{array}{c}-0.00314 \\
(0.102)\end{array}$ \\
\hline Nest leaving of children & $\begin{array}{c}-0.914 * * * \\
(0.0972)\end{array}$ & $\begin{array}{r}-0.396 \\
(0.342)\end{array}$ \\
\hline Age at nest leaving & $\begin{array}{r}-0.00491 \\
(0.00630)\end{array}$ & $\begin{array}{c}0.00845 \\
(0.0123)\end{array}$ \\
\hline Still at home & $\begin{array}{c}-1.675^{* * *} \\
(0.298)\end{array}$ & $\begin{array}{r}-0.949 \\
(0.630)\end{array}$ \\
\hline Poor health & $\begin{array}{l}0.812 * * * \\
(0.127)\end{array}$ & $\begin{array}{c}0.471 * \\
(0.270)\end{array}$ \\
\hline Worse health & $\begin{array}{c}-1.797 * * * \\
(0.229)\end{array}$ & $\begin{array}{c}-1.418^{* *} \\
(0.595)\end{array}$ \\
\hline Better health & $\begin{array}{c}-3.010 * * * \\
(0.331)\end{array}$ & $\begin{array}{c}-2.584 * * * \\
(0.644)\end{array}$ \\
\hline Hardship & $\begin{array}{r}-0.0517 \\
(0.145)\end{array}$ & $\begin{array}{r}-0.846^{*} \\
(0.462)\end{array}$ \\
\hline Hardship start & $\begin{array}{r}-0.535^{*} \\
(0.316)\end{array}$ & \\
\hline Hardship end & $\begin{array}{r}-0.518 \\
(0.340)\end{array}$ & \\
\hline Many books & $\begin{array}{c}0.327 * * * \\
(0.0759)\end{array}$ & $\begin{array}{c}0.292 \\
(0.179)\end{array}$ \\
\hline Overcrowd & $\begin{array}{l}-0.121 \\
(0.0791)\end{array}$ & $\begin{array}{c}0.211 \\
(0.160)\end{array}$ \\
\hline Good mathematics & $\begin{array}{l}0.244 * * * \\
(0.0723)\end{array}$ & $\begin{array}{r}-0.213 \\
(0.168)\end{array}$ \\
\hline
\end{tabular}


Table 5 (continued)

\begin{tabular}{lcc}
\hline Variables & 1 & 2 \\
& $\begin{array}{l}\text { Rent-own } \\
\text { (under 65) }\end{array}$ & $\begin{array}{l}\text { Rent-own } \\
\text { (over 65) }\end{array}$ \\
\hline Good verbal & $0.179 * *$ & $0.585^{* * * *}$ \\
Constant & $(0.0741)$ & $(0.170)$ \\
& $-1.897 * * *$ & $-4.877 * * *$ \\
Observations & $(0.248)$ & $(0.630)$ \\
\hline
\end{tabular}

All specifications include a full set of country, age bracket and decade dummies. Reference group: no change. Robust standard errors in parentheses

$* p<0.1 ; * * p<0.05 ; * * * p<0.01$

lack of asset decumulation in old age. In their model, that captures the salient features of the US welfare system and stylized facts from US micro-data documented by Venti and Wise (2004), retired households face health risks, medical expense risks and longevity risks (as by De Nardi et al. 2010 and Poterba et al. 2010), affecting

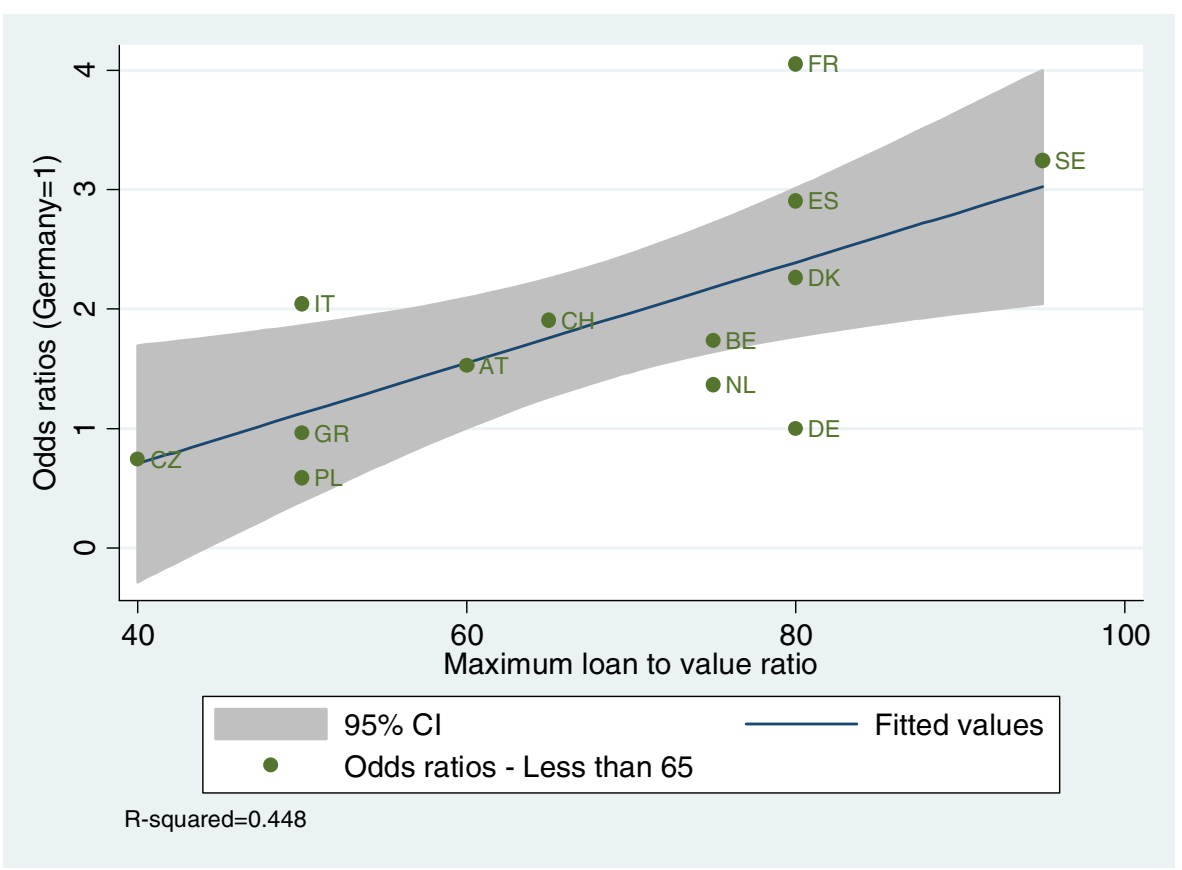

Fig. 5 Purchase probability for the 50-64 age bracket and mortgage availability 
Table 6 Probability of moving into rented accommodation for the $65+$ as a function of the house valueto-income ratio

\begin{tabular}{|c|c|c|c|}
\hline Variables & $\begin{array}{l}1 \\
\text { Own-rent }\end{array}$ & $\begin{array}{l}2 \\
\text { Own-rent } \\
\text { (excluding rent-free) }\end{array}$ & $\begin{array}{l}3 \\
\text { Own-rent } \\
\text { (excluding rent-free) }\end{array}$ \\
\hline Female & $\begin{array}{l}0.148 \\
(0.142)\end{array}$ & $\begin{array}{l}0.0982 \\
(0.153)\end{array}$ & $\begin{array}{c}0.136 \\
(0.150)\end{array}$ \\
\hline Childless & $\begin{array}{c}-0.604 * * \\
(0.293)\end{array}$ & $\begin{array}{r}-0.358 \\
(0.311)\end{array}$ & \\
\hline Number of children & $\begin{array}{r}-0.0950 \\
(0.0681)\end{array}$ & $\begin{array}{r}-0.00355 \\
(0.0753)\end{array}$ & \\
\hline Married & $\begin{array}{c}-0.792 * * * \\
(0.156)\end{array}$ & $\begin{array}{c}-0.848^{* * *} \\
(0.168)\end{array}$ & $\begin{array}{c}-0.803 * * * \\
(0.164)\end{array}$ \\
\hline Widowhood & $\begin{array}{l}0.978 * * * \\
(0.237)\end{array}$ & $\begin{array}{l}0.826^{* * *} \\
(0.279)\end{array}$ & $\begin{array}{l}0.828 * * * \\
(0.276)\end{array}$ \\
\hline Divorce & $\begin{array}{l}3.069 * * * \\
(0.567)\end{array}$ & $\begin{array}{l}3.205^{* * *} \\
(0.592)\end{array}$ & $\begin{array}{l}3.175^{* * *} \\
(0.621)\end{array}$ \\
\hline No. of children in starting year & $\begin{array}{c}0.235 * * \\
(0.0946)\end{array}$ & $\begin{array}{r}0.0817 \\
(0.130)\end{array}$ & \\
\hline Nest leaving of children & $\begin{array}{c}-0.295 \\
(0.428)\end{array}$ & $\begin{array}{r}-0.273 \\
(0.574)\end{array}$ & \\
\hline Age at nest leaving & $\begin{array}{c}-0.0214 * \\
(0.0130)\end{array}$ & $\begin{array}{r}-0.0121 \\
(0.0135)\end{array}$ & \\
\hline Poor health & $\begin{array}{l}0.931 * * * \\
(0.201)\end{array}$ & $\begin{array}{l}0.931 * * * \\
(0.222)\end{array}$ & $\begin{array}{l}0.945^{* * *} \\
(0.222)\end{array}$ \\
\hline Worse health & $\begin{array}{r}-0.126 \\
(0.373)\end{array}$ & $\begin{array}{r}-0.0873 \\
(0.435)\end{array}$ & $\begin{array}{r}-0.0757 \\
(0.436)\end{array}$ \\
\hline Better health & $\begin{array}{c}-2.700 * * * \\
(0.624)\end{array}$ & $\begin{array}{c}-2.906^{* * *} \\
(0.751)\end{array}$ & $\begin{array}{c}-2.899 * * * \\
(0.750)\end{array}$ \\
\hline Hardship & $\begin{array}{c}-0.0199 \\
(0.472)\end{array}$ & $\begin{array}{c}0.700 \\
(0.475)\end{array}$ & $\begin{array}{c}0.756 \\
(0.470)\end{array}$ \\
\hline Hardship start & $\begin{array}{c}1.021 \\
(0.730)\end{array}$ & $\begin{array}{c}1.418^{*} \\
(0.799)\end{array}$ & $\begin{array}{c}1.477 * \\
(0.766)\end{array}$ \\
\hline Many books & $\begin{array}{c}-0.366^{* *} \\
(0.155)\end{array}$ & $\begin{array}{c}-0.309^{*} \\
(0.161)\end{array}$ & $\begin{array}{c}-0.360^{* *} \\
(0.158)\end{array}$ \\
\hline Overcrowding & $\begin{array}{l}0.0845 \\
(0.158)\end{array}$ & $\begin{array}{r}-0.0247 \\
(0.182)\end{array}$ & \\
\hline Good mathematics & $\begin{array}{r}-0.162 \\
(0.153)\end{array}$ & $\begin{array}{r}-0.206 \\
(0.163)\end{array}$ & \\
\hline Good verbal & $\begin{array}{r}-0.151 \\
(0.153)\end{array}$ & $\begin{array}{r}-0.176 \\
(0.161)\end{array}$ & \\
\hline
\end{tabular}


Table 6 (continued)

\begin{tabular}{llll}
\hline Variables & 1 & 2 & 3 \\
& Own-rent & $\begin{array}{l}\text { Own-rent } \\
\text { (excluding rent-free) }\end{array}$ & $\begin{array}{l}\text { Own-rent } \\
\text { (excluding rent-free) }\end{array}$ \\
\hline Constant & $-1.197 * * *$ & $-1.551 * * *$ & $-2.078^{* * *}$ \\
Observations & $(0.462)$ & $(0.507)$ & $(0.355)$ \\
\hline
\end{tabular}

All specifications include a full set of country, age bracket and decade dummies. Reference group: no change. Robust standard errors in parentheses

$* p<0.1 ; * * p<0.05 ; * * * p<0.01$

both spouses. Their incomes are stable in real terms (except when either spouse dies), and house price inflation is known in advance by consumers. A distinctive feature of their model is the separation between housing wealth and financial wealth. Financial wealth can be held by all, whilst housing wealth, only by homeowners (other real estate and own business are ignored). Homeowners can sell and become renters but pay a large transaction cost when they do (as in Yang 2009) — renters cannot become homeowners, but can change their consumption of housing services at no cost.

Crucial to their analysis are three assumptions they make:

1. Homeowners enjoy housing services more than renters (there is a "pride of ownership" term in the utility function) - this is meant to capture the insurance properties of homeownership, tax advantages granted to homeowners, the fundamental rental externality discussed by Henderson and Ioannides (1983), as well as the extra freedom owners have of adapting their homes to their changing needs.

2. Renters cannot borrow; homeowners can, but are subject to collateral constraints that change with age.

3. Both homeowners and renters have a bequest motive.

They estimate a number of preference parameters (including risk aversion, pride of ownership and the strength of the bequest motive) as well as the size of collateral constraints. Their estimates imply that borrowing becomes less and less easy for homeowners as they age, in line with observed debt behaviour of the different cohorts considered in their study.

In their analysis, downsizing is typically triggered by a major life event like the loss of one's spouse or deteriorating health (that brings about the need for extra medical expenses), particularly in old age, when home equity release becomes more difficult.

Their results point to the key role played by the bequest motive. A standard life cycle model with longevity risk can explain 30-40\% of the observed median net worth of the post-retirement cohorts they consider in their application. With a bequest motive, this fraction increases with age, rising to at least $65 \%$ 
Table 7 Probability of moving into rented accommodation for the $65+$ as a function of house-rich, cashpoor indicators

\begin{tabular}{|c|c|c|c|}
\hline Variables & $\begin{array}{l}1 \\
\text { Own-rent }\end{array}$ & $\begin{array}{l}2 \\
\text { Own-rent } \\
\text { (excluding rent-free) }\end{array}$ & $\begin{array}{l}3 \\
\text { Own-rent } \\
\text { (excluding rent-free) }\end{array}$ \\
\hline Female & $\begin{array}{c}0.162 \\
(0.143)\end{array}$ & $\begin{array}{c}0.124 \\
(0.154)\end{array}$ & $\begin{array}{c}0.152 \\
(0.152)\end{array}$ \\
\hline Childless & $\begin{array}{c}-0.604 * * \\
(0.294)\end{array}$ & $\begin{array}{r}-0.360 \\
(0.312)\end{array}$ & \\
\hline Number of children & $\begin{array}{c}-0.0908 \\
(0.0679)\end{array}$ & $\begin{array}{r}0.00117 \\
(0.0751)\end{array}$ & \\
\hline Married & $\begin{array}{c}-0.776^{* * * *} \\
(0.169)\end{array}$ & $\begin{array}{c}-0.876^{* * * *} \\
(0.185)\end{array}$ & $\begin{array}{c}-0.783 * * * \\
(0.169)\end{array}$ \\
\hline Widowhood & $\begin{array}{l}0.961 * * * \\
(0.241)\end{array}$ & $\begin{array}{l}0.848^{* * *} \\
(0.284)\end{array}$ & $\begin{array}{l}0.821 * * * \\
(0.276)\end{array}$ \\
\hline Divorce & $\begin{array}{l}3.175^{* * *} \\
(0.551)\end{array}$ & $\begin{array}{l}3.338 * * * \\
(0.576)\end{array}$ & $\begin{array}{l}3.272 * * * \\
(0.594)\end{array}$ \\
\hline No. children in start year & $\begin{array}{l}0.233 * * \\
(0.0945)\end{array}$ & $\begin{array}{c}0.0817 \\
(0.130)\end{array}$ & \\
\hline Nest leaving of children & $\begin{array}{r}-0.303 \\
(0.429)\end{array}$ & $\begin{array}{r}-0.262 \\
(0.574)\end{array}$ & \\
\hline Age at nest leaving & $\begin{array}{c}-0.0195 \\
(0.0129)\end{array}$ & $\begin{array}{c}-0.0101 \\
(0.0134)\end{array}$ & \\
\hline Poor health & $\begin{array}{l}0.919 * * * \\
(0.202)\end{array}$ & $\begin{array}{l}0.917 * * * \\
(0.222)\end{array}$ & $\begin{array}{l}0.929 * * * \\
(0.222)\end{array}$ \\
\hline Worse health & $\begin{array}{r}-0.130 \\
(0.373)\end{array}$ & $\begin{array}{r}-0.0919 \\
(0.434)\end{array}$ & $\begin{array}{c}-0.0810 \\
(0.436)\end{array}$ \\
\hline Better health & $\begin{array}{c}-2.722 * * * \\
(0.624)\end{array}$ & $\begin{array}{c}-2.931 * * * \\
(0.751)\end{array}$ & $\begin{array}{c}-2.921 * * * \\
(0.750)\end{array}$ \\
\hline Hardship & $\begin{array}{c}-0.0235 \\
(0.477)\end{array}$ & $\begin{array}{c}0.695 \\
(0.484)\end{array}$ & $\begin{array}{c}0.728 \\
(0.475)\end{array}$ \\
\hline Hardship start & $\begin{array}{c}1.016 \\
(0.742)\end{array}$ & $\begin{array}{c}1.400 * \\
(0.808)\end{array}$ & $\begin{array}{c}1.435 * \\
(0.785)\end{array}$ \\
\hline Many books & $\begin{array}{c}-0.356^{* *} \\
(0.156)\end{array}$ & $\begin{array}{r}-0.305^{*} \\
(0.161)\end{array}$ & $\begin{array}{c}-0.342 * * \\
(0.158)\end{array}$ \\
\hline Overcrowd & $\begin{array}{c}0.0719 \\
(0.158)\end{array}$ & $\begin{array}{r}-0.0379 \\
(0.184)\end{array}$ & \\
\hline Good mathematics & $\begin{array}{r}-0.135 \\
(0.154)\end{array}$ & $\begin{array}{r}-0.180 \\
(0.165)\end{array}$ & \\
\hline Good verbal & $\begin{array}{r}-0.142 \\
(0.152)\end{array}$ & $\begin{array}{r}-0.171 \\
(0.159)\end{array}$ & \\
\hline Low income & $\begin{array}{r}-0.0509 \\
(0.186)\end{array}$ & $\begin{array}{r}-0.143 \\
(0.204)\end{array}$ & \\
\hline
\end{tabular}


Table 7 (continued)

\begin{tabular}{lccc}
\hline Variables & 1 & 2 & 3 \\
& Own-rent & $\begin{array}{l}\text { Own-rent } \\
\text { (excluding rent-free) }\end{array}$ & $\begin{array}{l}\text { Own-rent } \\
\text { (excluding rent-free) }\end{array}$ \\
\hline House-rich, cash-poor & & $-1.209 * * *$ & $-1.203 * * *$ \\
House-rich, cash-poor $\times$ low income & $1.124 * * *$ & $1.096^{* * *}$ & $(0.322)$ \\
Constant & $(0.382)$ & $(0.411)$ & $1.005^{* * *}$ \\
& $-1.218^{* * *}$ & $-1.503 * * *$ & $(0.378)$ \\
Observations & $(0.472)$ & $(0.519)$ & $-2.052^{* * *}$ \\
\hline
\end{tabular}

All specifications include a full set of country, age bracket and decade dummies. Reference group: no change. Robust standard errors in parentheses

$* p<0.1 ; * * p<0.05 ; * * * p<0.01$

of median net worth for the youngest cohort and at most $90 \%$ for the oldest. Health and medical expenditure risks play some role for younger old, but not an important one for the other cohorts (at least at the median). Collateral constraints are also important and explain more of median net worth holdings than pride of ownership.

The results from structural estimation cited above are entirely based on US evidence. The question arises as to what extent these are driven by particular institutional details or access to equity release schemes for elderly homeowners.

In this section, we therefore provide prima facie evidence for European countries on what affects the probability of selling their home for elderly consumers by taking into consideration some economic variables that the theoretical model suggest are likely to play a role.

In particular, we investigate the role of the following factors in triggering a transition from owning to renting (broadly defined to include all sorts of housing arrangements other than ownership):

1. For individuals in poor health-whose medical or personal care expenses are projected to increase over the years-moving into rented accommodation releases wealth.

2. For individuals who lost their spouse, pension income may fall, plus the desired balance between non-durable consumption and housing services is affected, making them more likely to downsize.

3. Individuals high on housing wealth and low on financial wealth (house-rich, cash-poor, according to the definition of Mitchell and Piggott 2003 and Venti and Wise 2004) are more likely to move into rented accommodation as they grow old. This is likely to be more important among the lower-income group. 
Finally, individuals who enjoy a higher lifetime wealth are more likely to have financial wealth as well as housing wealth and are therefore less likely to be induced to trade down by financial considerations.

In Table 6, we explore the role played by the illiquid nature of housing wealth in prompting a move from owning to rented accommodation after age 65 . We focus on those owners who either made no move or moved into rented accommodation during the 5-year interval. We therefore drop from our sample those who rented at the beginning of the period and those who engaged in an own-own transition during the period.

For each individual, we compute the ratio of housing wealth to current income at the beginning of the period. According to the theoretical prediction highlighted in point 3 above, we expect that a high ratio should induce a move into rented accommodation, if financial forms of housing equity withdrawal are not available.

The numerator of this ratio, the value of housing wealth at the beginning of the period, is either known, for those who sold during the period, or can be imputed, by inflating or deflating the 2006 self-assessed house values as reported in a previous wave of SHARE. Inflation/deflation was implemented by using countryspecific house price indices. We had to drop all observations from Poland and the Czech Republic because of the limited availability of house price indices for these countries.

The denominator of this ratio is given either by current pension income or by the pension income that was earned at the beginning of the period. Given that pension incomes are typically stable in real terms, except in case of the loss of a spouse, when income typically decreases by $40 \%$, we can construct a measure for all individuals.

The resulting house-income ratio has a median of 5.25, a 25th percentile of 2.10 and a 75 th percentile of 9.92 .

The first column in Table 6 presents the results for the sample of 12,373 homeowners who either did not move or sold and moved into rented accommodation. The estimated parameters show that childless individuals are significantly less likely to sell-a surprising result, particularly in light of the evidence that homeownership can be a way to lure your children into looking after you in old age (Angelini 2007). The overall number of children the respondent ever had has a negative, but insignificant effect, whilst the number of children still living with the respondent has a significant positive effect. This pattern of coefficients is hard to interpret because of the broad definition of rented accommodation we adopt in the paper, which includes also rent-free accommodation (that may be living at the place of one's grown children).

For this reason, we show in columns 2 and 3 of Table 6 the estimated coefficients for the sample of individuals who either did not move, or moved into rented accommodation, strictly defined. The new sample size is 10,846 observations: even though only 38 individuals transit to rent-free accommodation, once these are excluded, there are no transitions left in Greece, and all Greek observations are dropped from the analysis. The indicator for a childless individual loses its statistical significance, and so do all other variables relating to children. This does not lend support to the notion that housing wealth is retained because of a bequest motive.

Health has an interesting, non-linear effect on the transition from owning to renting. A negative health shock has no effect, but persistent poor health makes you more 
likely to move. A health improvement, on the other hand, strongly reduces the transition probability. This pattern of coefficients suggests that a transition from owning to renting may be the end result of the "asset cost of poor health" that is documented by Poterba et al. (2010): when elderly homeowners are affected by a negative health shock, they will first stay put (and possibly deplete their housing stock by cutting on maintenance expenses, something we unfortunately do not observe in our data), but if the shock is persistent and leads to sustained care costs, they may end up selling and moving to rented accommodation. If the shock is not persistent and their health recovers, instead, they will stay in their homes.

We see in both the more general specification in column 2 and in the parsimonious specification in column 3 that housing wealth-to-income ratio has a significant positive effect on the probability of moving into rented accommodation, after controlling for the same set of explanatory variables in Table 5.

The ratio of housing wealth to income can be high if the numerator is large or if the denominator is small. Given that the numerator is likely to correlate strongly with total household wealth, the ratio may be a poor indicator for the presence of a houserich, cash-poor individual. For this reason, we construct some indicators that may better capture the notion of individuals with little income but with a lot of unused housing equity.

Table 7 reports parameter estimates of a specification that includes instead of the housing wealth-to-income ratio a low-income indicator (country-level lowest quartile), a house-rich, cash-poor indicator, that takes a value of 1 if the ratio is in the top country-level quartile, and their interaction. On average, $12 \%$ households are classified as both low-income and house-rich and cash-poor. As in Table 6, column 1 considers all transitions, whilst columns 2 and 3 drop transitions into rent-free accommodation.

In all specifications in Table 7 (but also Table 6), we find that health variables have a significant effect on the probability to transit into rented accommodation: poor health has a positive effect, whilst health improvement has a strong, negative effect. In principle, the effects of health shocks and of housing wealth could be different across countries, because of differences in the prevailing types of long-term care (LTC) arrangements. In Nordic countries and The Netherlands, LTC is provided by the government; in Southern countries (Italy, Spain and Greece), it is the responsibility of the family, with limited help provided by public authorities. In the remaining countries, there is a mix of financial and logistic support from the government and family or informal care.

We therefore constructed indicators for countries belonging to each type of LTC arrangement and interacted with them all health and housing wealth variables in Tables 6 and 7. We find that the coefficients on these interaction terms are hard to interpret and never jointly significant and conclude therefore that institutional differences in LTC arrangements do not generate heterogeneity of response of own-to-rent transition probabilities to health and wealth variables.

In Table 7, we see that in both columns 1 and 2, the low-income indicator is not significant (and is therefore dropped in column 3), and the house-rich, cash-poor indicator has a negative effect, but its interaction with low-income has a significantly positive effect. 
The negative effect of the house-rich, cash-poor dummy is apparently counterintuitive. It can be explained if we consider that, for most individuals, a high home value is associated with high financial wealth (that we do not observe).

The positive effect of the interaction between the house-rich, cash-poor dummy and the low-income dummy is in line with the notion that the cash value of the home is tapped in by low-income households by moving into rented accommodation. For low-income people, their home can be a way to finance non-housing consumption in old age.

A question that comes to mind is how individuals who are house-rich and cash-poor and have low income make ends meet. A possibility is that they receive help from their children. Based on data on financial transfers reported in the second wave of SHARE, this is not a common occurrence. Among homeowners aged 65 or over, only $3.67 \%$ report having received financial help worth 250 Euros or more over the previous 12 months. This fraction is slightly higher among lowincome individuals who are house-rich and cash-poor (4.32\%) but too low to suggest that informal insurance across generations is a widespread phenomenon that can explain why low-income homeowners do not trade down or cash in on their home in older ages.

All regressions control for country fixed effects - these reflect time-invariant features not only of the social insurance systems and of the tax system (that is normally not neutral between owning and renting) but also of the housing market, such as rent regulations and transaction costs.

Transaction costs are of particular interest to our analysis, as they may be responsible for the widespread failure to tap in home equity in old age by trading down or selling and becoming a tenant. All countries in our sample levy taxes on housing transactions and/or registration fees; in all countries, estate agents are paid a fee from either party (or both), and solicitors (or notaries) also are paid non-negligible fees. Even though these transaction costs are nominally attributed to sellers or buyers in various ways, in equilibrium, they are borne by both parties.

We therefore sum all taxes and fees due by the seller or buyer in each country and produce an estimate of average transaction costs - we can relate this to the estimated country fixed effects. We used the data collected by OECD (see Andrews et al. 2011, particularly Fig. 27) on these transaction costs. These refer to a point in time (2009), as we could not find comparable data for other years. But the relative ranking of countries is unlikely to have changed much over the last two or three decades, at least in the continental European countries we consider (which do not include Poland and the Czech Republic).

We observe that these costs are lowest in Denmark (less than $3 \%$ of the purchase price), followed by Sweden, Switzerland, The Netherlands and Germany (between 6 and $8 \%$ ); highest in Belgium, Greece, France and Austria (between 14 and $15 \%$ ), followed by Italy and Spain (between 11 and $12 \%$ ).

In Fig. 6, we plot round-trip transaction costs against the odds ratios of becoming a renter associated to the country dummy coefficient in column 3 of Table 7 . We find a strong, negative relation in agreement with the theoretical predictions of the 


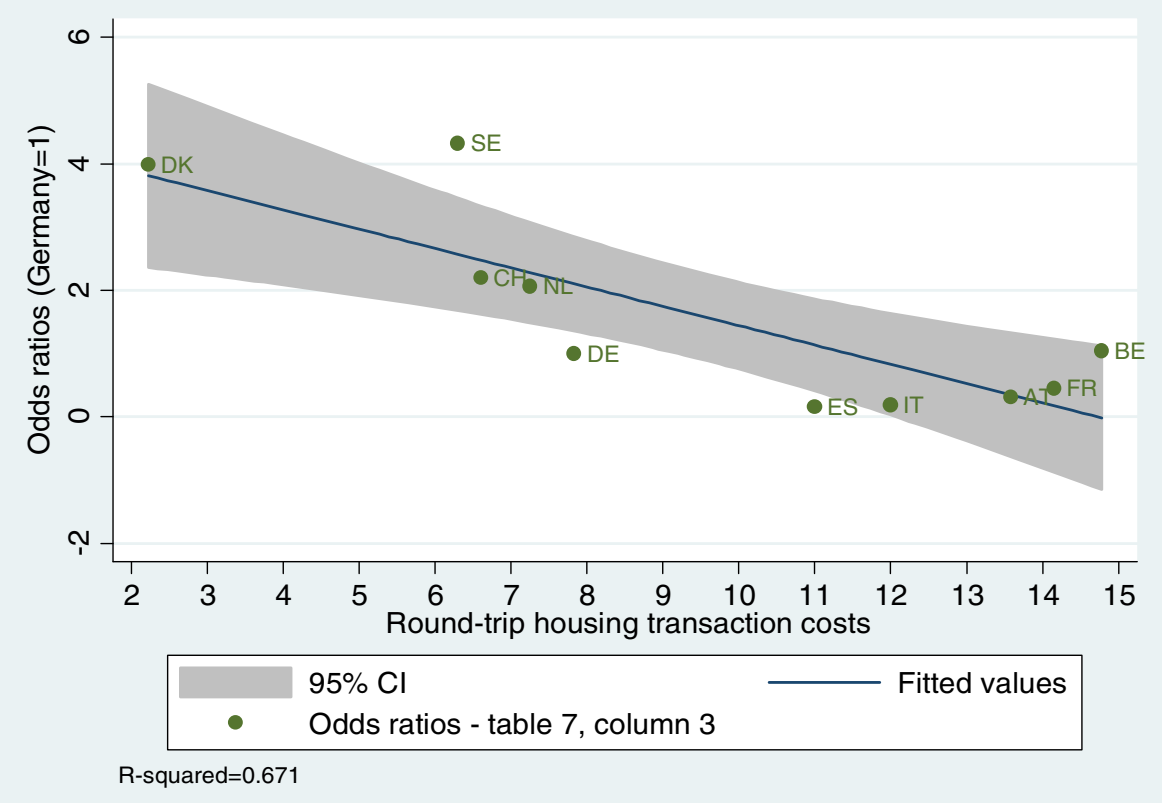

Fig. 6 Sale probability for the $65+$ age bracket and transaction costs in the housing market

life cycle model with borrowing constraints and transaction costs developed by Yang (2009).

\section{Conclusions}

This paper has addressed two related topics: residential mobility among mature households in Europe and homeownership patterns in old age.

We have exploited a unique data set, the life history wave of SHARE, to identify the key patterns in residential mobility of European 50+ individuals. The retrospective data show some marked differences in mobility across countries and age. Residential mobility is higher in Nordic countries and particularly low in Mediterranean countries. Transitions from rented accommodation to homeownership are relatively common until retirement age, whilst moves from owning to renting and from more expensive to less expensive homes are rare, but become relatively more important past the retirement age.

Our econometric analysis reveals that moves from homeownership to rented accommodation before age 65 are largely driven by demographic events (particularly divorce and loss of spouse), whilst the reverse move is also negatively affected by financial hardship, nest leaving by children and poor health and positively affected by a more educated home environment during childhood. 
Moves later in life are more frequently explained by health-related factors. Moves from homeownership to rented accommodation are more likely for those in poor health and for those who divorced or whose spouse died, but much less likely for those who grew up in a more educated environment. Decisions of trading down or up for homeowners are more difficult to explain.

The topic of homeownership patterns in old age has attracted much attention by economists for a number of reasons. First of all, the life cycle model with imperfect credit markets predicts that homeowners should either trade down or move into rented accommodation in old age, as a way to smooth consumption. Secondly, failure to tap in home equity in old age may create financial problems to homeowners at times of need. Given the limited access to debt markets for the elderly in all countries, failure to sell one's home and to move into rented accommodation may result in financial hardship and inability to cover health-care costs. The evidence we provided in the paper shows that changes in health and loss of spouse are key determinants of the decision to sell one's home past the age of 65, but that house-rich, cash-poor consumers are also more likely to sell if their income is sufficiently low. It also shows that transaction costs play an important role in explaining why in some countries, in particular, many elderly homeowners do not become renters in old age.

Acknowledgments We thank two referees for their extremely useful comments and suggestions. We are also grateful for comments made by the audiences at the Labour Economics Workshop, Brixen, May 2011; the Bank of Italy-Dondena Workshop on Public Policies, Social Dynamics and Population, July 2011; and the European University Institute, October 2011. This paper uses data from SHARELIFE release 1, as of November 24, 2010 or SHARE release 2.4.0, as of March 17, 2011. The SHARE data collection has been primarily funded by the European Commission through the 5th Framework Programme (project QLK6-CT-2001-00360 in the thematic programme Quality of Life), through the 6th Framework Programme (projects SHARE-I3, RII-CT-2006-062193, COMPARE, CIT5-CT-2005-028857, and SHARELIFE, CIT4-CT-2006-028812) and through the 7th Framework Programme (SHARE-PREP, 211909 and SHARE-LEAP, 227822). Additional funding from the US National Institute on Aging (U01 AG09740-13S2, P01 AG005842, P01 AG08291, P30 AG12815, Y1-AG-4553-01 and OGHA 04-064, IAG BSR06-11, R21 AG025169) as well as from various national sources is gratefully acknowledged (see www.share-project.org for a full list of funding institutions).

\section{References}

Andrews D, Caldera Sanchez A, Johansson $\AA$ (2011) Housing market and structural policies in OECD countries. OECD Economics Department Working Paper 836. OECD, Paris

Angelini V (2007) The strategic bequest motive: evidence from SHARE. "Marco Fanno" Working Papers 0062. Dipartimento di Scienze Economiche, Università di Padova, Padua

Angelini V, Brugiavini A, Weber G (2009) Ageing and unused capacity in Europe: is there an early retirement trap? Econ Policy 59:463-508

Angelini V, Brugiavini A, Weber G (2011) Does downsizing of housing equity alleviate financial distress in old age? In: Börsch-Supan A, Brandt M, Hank K, Schröder M (eds) Individual and the welfare state. Life histories in Europe. Springer, Heidelberg, pp 93-101

Angelini V, Laferrère A, Weber G (2011) Homeownership in old age at the crossroad between personal and national histories. In: Börsch-Supan A, Brandt M, Hank K, Schröder M (eds) Individual and the welfare state. Life histories in Europe. Springer, Heidelberg, pp 81-92

Artle R, Varaiya P (1978) Life cycle consumption and ownership. J Econ Theory 18:35-58

Attanasio OP, Banks J, Meghir C, Weber G (1999) Humps and bumps in lifetime consumption. J Bus Econ Stat 17:22-35 
Attanasio OP, Bottazzi R, Low H, Nesheim L, Wakefield M (2011) Modelling the demand for housing over the lifecycle. Rev Econ Dyn 15:1-18

Banks J, Blundell R, Oldfield Z, Smith JP (2012) Housing mobility and downsizing at older ages in Britain and the United States. Economica 79:1-26

Börsch-Supan A, Brandt B, Hank K, Schröder M (2011) The individual and the welfare state. Life histories in Europe. Springer, Heidelberg

Chiuri MC, Jappelli T (2010) Do the elderly reduce housing equity? An international comparison. J Popul Econ 23:643-663

De Nardi M, French E, Jones JB (2010) Why do the elderly save? The role of medical expenses. J Polit Econ 118:39-75

Henderson JV, Ioannides YM (1983) A model of housing tenure choice. Am Econ Rev 73:98-111

Mitchell OS, Piggott J (2003) Housing equity and senior security. ESRI International Conference, NBER WP 12444. Forthcoming. In: Tachibanaki T (ed) New challenges for social security. NBER, Tokyo

Nakajima M, Telyukova IA (2011) Home equity withdrawal in retirement. Federal Reserve Bank of Philadelphia, Philadelphia

Poterba JM, Venti SF, Wise DA (2010) The asset cost of poor health. NBER Working Papers 16389. NBER, Cambridge

Sinai T, Souleles NS (2005) Owner-occupied housing as a hedge against rent risk. Q J Econ 120:763-789

Venti SF, Wise DA (2004) Aging and housing equity: another look. In: Wise DA (ed) Perspectives on the economics of aging. University of Chicago Press, Chicago, pp 127-180

Yang F (2009) Consumption over the life cycle: how different is housing? Rev Econ Dyn 12:423-443 